\title{
PENERAPAN ANALISIS REGRESI DUMMY PADA DATA KUALITATIF KASUS EKONOMI
}

\author{
Roza Zelvia \\ IAIN Metro, Lampung \\ E-mail:zelvia_roza@yahoo.co.id \\ Alva Yenica Nandavita \\ IAIN Metro, Lampung \\ E-mail:zelvia_roza@yahoo.co.id \\ Hotman \\ IAIN Metro, Lampung \\ alvanandaE-mail: hotman@yahoo.co.id
}

\begin{abstract}
Regression analysis is basically the study of the dependence of one variable dependent (response/non-free) with one or more variables independent (explanatory / free), in order to estimate and / or predict the average population or the average value of the variable dependent based on the value independent variables that are known.In some economy cases, we ussualy would like to look at the relationship between variabel, such as the relationship between the profit of the company with the types of company, income customers who finance with the amount of funding requested and the salary earned by the employees with education and work experience of the employee itself. However, dealing with the variables of economy cases, there are many variables that are ordinal or nominal scale called qualitative data. Therefore, it can not only be solved by using a simple regression analysis or multiple regressions. Moreover, Dummy regression analysis is one of the solutions in dealing with cases of economic data with qualitative independent variables. This paper will investigate the economic case data which have the categorical independent variables by using dummy regression analysis. The data used in this literature study is secondary data obtained from the data already
\end{abstract}

Jurnal Hukum dan Ekonomi Syariah, Vol. 05 Nomor 1 
published to the Internet. Furthermore, based on data analysis, it was found that, in the dummy regression analysis, it was allowed more than one Independent variables, where the variables can interact or have no interaction each other. Those can be drawn by a scatterplot of the data.

Keywords: dummy regression, qualitative data, regression analysis. 



\begin{abstract}
Abstrak
Analisis regresi pada dasarnya adalah studi mengenai ketergantungan satu peubah dependen (respon/tak bebas) dengan satu atau lebih peubah independen (penjelas/bebas), dengan tujuan untuk mengestimasi dan/atau memprediksi rata-rata populasi atau nilai rata-rata peubah dependen berdasarkan nilai peubah independen yang diketahui.Dalam beberapa kasus ekonomi, sering kali kita ingin melihat hubungan antar peubah, seperti hubungan antara laba perusahaan dengan tipe perusahaan, gaji yang diperoleh karyawan dengan jenjang pendidikan dan pengalaman kerja karyawan tersebut. Namun, pada peubah-peubah dalam kasus ekonomi tersebut terdapat banyak peubah yang berskala ordinal atau nominal yang disebut juga data kualitatif. Sehingga dalam penyelasaian kasus tersebut tidak bisa dilakukan analisis regresi sederhana atau regresi berganda biasa. Analisis regresi dummy adalah salah satu solusi dalam menghadapi kasus data ekonomi dengan peubah bebas yang bersifat kualitatif. Tulisan ini akan menelusuri data kasus ekonomi yang memiliki peubah bebas bersifat kategorik dengan menggunakan analisis regresi dummy. Data yang digunakan dalam penelitian pustaka ini adalah data sekunder yang diperoleh dari data yang sudah di publish ke internet.Berdasarkan analisis data tersebut, peubah bebas pada analisis regresi dummy boleh lebih dari satu, dimana peubah-peubah tersebut bisa saling berinteraksi atau tidak saling berinteraksi. Hal ini ditunjukkan dari gambar scatterplot dari data tersebut.
\end{abstract}

Kata kunci: regresi dummy, data kualitatif, analisis regresi.

\title{
Pendahuluan
}

Analisis regresi dipergunakan untuk mengetahui hubungan fungsional antara peubah-peubah yang dinyatakan dalam bentuk persamaan matematik dan garis. Persamaan matematik dan garis yang didapat disebut dengan persamaan regresi yang dapat berbentuk garis lurus (linear) dan atau tidak lurus (non linear). Hubungan fungsional terdiri dari dua jenis peubah yaitu peubah bebas (independent) dan peubah tak bebas (dependent). ${ }^{1}$ Dalam kehidupan sehari-hari, sering kali kita ingin melihat hubungan Dipantara (Anggota Ikapi), 2015), h. 444. 
antarpeubah, seperti hubungan antara panjang dan bobot bayi, tingkat pendidikan ibu dan gizi balita dalam kasus sosial. Hubungan tersebut juga terdapat dalam kasus ekonomi, seperti ingin melihat hubungan antara laba perusahaan dengan tipe perusahaan, pendapatan nasabah yang melakukan pembiayaan dengan jumlah pembiayaan yang diminta.

Dalam menentukan mana yang menjadi peubah bebas dan peubah terikat tidaklah mudah, perlu dikaji berdasarkan teori-teori pendukung.Misalnya tipe perusahaan dapat dijadikan sebagai peubah bebas dan laba perusahaan sebagai peubah terikat, atau sebaliknya.Secara kuantitatif, hubungan antara peubah bebas dan peubah tak bebas tersebut dapat kita modelkan dalam suatu persamaan matematik, sehingga kita dapat menduga nilai suatu peubah tak bebas bila diketahui nilai dari peubah bebasnya. Persamaan matematik yang menggambarkan hubungan antara peubah bebas dan tak bebas sering disebut persamaan regresi. ${ }^{2}$

Persamaan regresi dengan satu peubah bebas dan satu peubah tak bebas disebut regresi sederhana, misalnya persamaan yang menggambarkan hubungan antara tinggi bapak dan tinggi anak laki-lakinya.Dalam contoh ini, tinggi bapak sebagai peubah bebas dan tinggi anak sebagai peubah tak bebas.Persamaan dengan beberapa peubah bebas dengan satu peubah tak bebas disebut regresi berganda, misalnya hubungan antara peubah bebas tingkat pendidikan, pendapatan, dan jumlah anak terhadap peubah tak bebas pengeluaran konsumsi keluarga. ${ }^{3}$

Hasil analisis regresi adalah berupa koefisien regresi untuk masing-masing peubah bebas. Koefisien ini diperoleh dengan cara memprediksi nilai peubah tak bebas dengan suatu persamaan. Koefisien regresi dihitung dengan dua tujuan sekaligus: Pertama, meminimumkan penyimpangan antara nilai aktual dan nilai estimasi peubah tak bebas; Kedua, mengoptimalkan korelasi antara nilai aktual dan nilai estimasi peubah tak bebas berdasarkan data yang ada. Teknik estimasi peubah tak bebas yang melandasi analisis regresi disebut Ordinary Least Squares (kuadrat terkecil).

2 Ahad,_nsori Mattjik, dan I Made, Sumertajaya, Perancangan Percobaan dengan Aplikasi SAS dan Minitab, (Bogor: IPB Press, 2000), h. 173.

${ }^{3}$ Ibid. 
Regresi metode kuadrat terkecil merupakan regresi yang sering dipakai pada saat data pada peubah respon merupakan numerik (kuantitatif).Namun pada data riil, seringkali data dalam bentuk kategorik (kualitatif).Sehingga data tersebut tidak akan cocok jika dianalisis menggunakan regresi sederhana atau regresi berganda biasa. Maka, dalam tulisan ini akan dibahas mengenai analisis regresi yang digunakan untuk peubah bebas kualitatif yaitu analisis regresi dummy dengan data kasus ekonomi.

\section{Sejarah Analisis Regresi}

Istilah regresi pertama kali diperkenalkan oleh Sir Francis Galton pada tahun 1886. Galton menemukan adanya tendensi bahwa orang tua yang memiliki tubuh tinggi memiliki anak-anak yang tinggi, orang tua yang pendek memiliki anak-anak yang pendek pula.Kendati demikian. Ia mengamati bahwa ada kecenderungan tinggi anak cenderung bergerak menuju rata-rata tinggi populasi secara keseluruhan. Dengan kata lain, ketinggian anak yang amat tinggi atau orang tua yang amat pendek cenderung bergerak kearah rata-rata tinggi populasi. Inilah yang disebut hukum Galton mengenai regresi universal. Dalam bahasa Galton, ia menyebutkan sebagai regresi menuju mediokritas.

Hukum regresi semesta (law of universal regression) dari Galton diperkuat oleh temannya Karl Pearson, yang mengumpulkan lebih dari seribu catatan tinggi anggota kelompok keluarga. Ia menemukan bahwa rata-rata tinggi anak laki-laki kelompok ayah (yang) pendek lebih besar dari pada tinggi ayah mereka, jadi "mundurnya" ("regressing") anak laki-laki yang tinggi maupun yang pendek serupa kearah rata-rata tinggi semua laki-laki. Dengan kata lain Galton, ini adalah "kemunduran kearah sedang".

Selanjutnya istilah "regression" ini digunakan untuk menggambarkan garis yang menunjukkan adanya hubungan antara 2 peubah. Ada beberapa ahli statistik yang lebih menyukai menggunakan "estimating line" atau "garis taksiran" daripada menggunakan istilah garis regresi. ${ }^{4}$

${ }^{4}$ Noegroho, Boedijoewono, Pengantar Statistika Ekonomi dan Bisnis, Jilid 1 (Deskriptif), (Yogyakarta: UPP STIM YKPN, 2016), h. 238 
Secara umum, analisis regresi pada dasarnya adalah studi mengenai ketergantungan satu peubah dependen (tak bebas) dengan satu atau lebih peubah independen (variabel penjelas/bebas), dengan tujuan untuk mengestimasi dan/ atau memprediksi rata-rata populasi atau nilai rata-rata peubah dependen berdasarkan nilai peubahindependen yang diketahui.Pusat perhatian adalah pada upaya menjelaskan dan mengevalusi hubungan antara suatu peubahdengan satu atau lebih peubahindependen.

\section{Skala Pengukuran}

Berbicara statistika tentu akan berbicara tentang data. Data merupakan kumpulan dari karakteristik objek/individu yang diamati atau sering juga disebut sebagai kumpulan dari peubahpeubah (variables).Berdasarkan skala pengukurannya, peubah dapat dikategorikan menjadi empat, yaitu peubah berskala nominal, ordinal, interval, dan rasio. ${ }^{5}$

Kita akan membahas tiga pengukuran berbeda, ketiganya berbeda dalam hal sejauh mana pengamatan-pengamatan dapat dibandingkan. Dalam urutan terendah sampai tertinggi ditinjau dari derajat pembandingan dapat dilakukan, skala-skala itu ialah nominal, ordinal, dan interval.

\section{Skala Nominal}

Skala pengukuran nominal adalah sejumlah kategori yang bervariasi dalam hal kualitas tertentu namun tidak dalam hal besarnya. Setiap pengamatan dapat diklasifikasikan ke dalam satu dan hanya satu kategori, yang seringkali menggambarkan jenis berbeda dari suatu fenomena.Misalnya jenis kelamin mempunyai skala (taraf-taraf) pria dan wanita.Peubah-peubah lainyang diukur dengan skala nominal ialah agama yang dianut, ras, pekerjaan, metode pembelajaran, jenis perusahaan dan status pekerjaan.Peubah yang diukur pada skala nominal dinamakan peubah nominal.Peubah nominal sering juga dinamakan peubah kualitatif, sebab dua nilai yang berbeda bagi peubah demikian ini

${ }^{5}$ Ahmad, Ansori Mattjik, dan I Made, Sumertajaya, Perancangan Percobaan dengan Aplikasi SAS dan Minitab, h. 7. 
berbeda dalam hal kualitas, bukan kuantitas.Meskipun kategori berbeda dari skala nominal disebut taraf skala, namun tidak ada taraf yang dapat ditafsirkan lebih besar, lebih tinggi, atau lebih kecil daripada taraf lainnya. Nama atau label dapat digunakan untuk mengidentifikasi kategori-kategori suatu peubah nominal, namun nama itu tidak mewakili besaran perbedaan nilai peubah tersebut. ${ }^{6}$

Angka-angka yang disajikan pada skala nominal hanya sebagai nama penggolongan. Angka tersebut tidak mengukur besaran tetapi hanya sebagai lambang.Dalam hal ini, angka 1 tidak lebih besar dari 0, begitu pula angka 0 tidak lebih kecil dari 1. Pemberian kode 1 pada laki-laki dan 0 pada perempuan, tidak berarti laki-laki mempunyai nilai 1 dan perempuan nol. Angka-angka tersebut hanyalah membedakan antara laki-laki dan perempuan, dengan demikian kita juga bisa menukar lakilaki menjadi 0 dan perempuan menjadi 1 tanpa merubah makna. ${ }^{7}$

\section{Skala Ordinal}

Bila nilai-nilai suatu peubah dapat dibandingkan dalam hal besarnya (magnitude), dengan nilai-nilai berbeda mewakili kuantitas-kuantitas berbeda pula, peubah demikian ini dinamakan kuantitatif. Setiap nilai yang mungkin dari suatu peubah kuantitatif selalu lebih besar atau lebih kecil dari nilai lainnya. Peubah kuantitatif yang paling kasar taraf-taraf pengukurannya diukur pada skala ordinal, dan dinamakan peubah ordinal.Ada urutan-urutan di antara nilai-nilai pada skala ordinal, namun jarak antara nilai-nilai tidak memiliki makna numerik yang pasti.Sebagian skala ordinal memberikan kepada setiap objek pengamatan peningkat yang terpisah (pertama, kedua, ketiga, dan seterusnya), misalnya tingkat keaktifan dalam kegiatan sosial, peringkat naik kelas, posisi pada hasil akhir suatu lomba, peringkat skor pada suatu ujian, dan kualitas produk. Untuk masing-masing peubah ini, kita dapat membandingkan dua

\footnotetext{
Bambang, Juanda, Ekonometrika Pemodelandan Pendugaan, (Bogor: IPB Press, 2009), h. 99-100.

${ }^{7}$ Ahmad, Ansori Mattjik, dan I Made, Sumertajaya, Perancangan Percobaan dengan Aplikasi SAS dan Minitab, h 8.
} 
pengamatan dengan cara mengatakan mana yang lebih besar (lebih tinggi peringkatnya) pada peubah tersebut.

Yang lebih sering dijumpai di dalam penelitian ilmu sosialadalah skala ordinal, yang terdiri atas suatu kumpulan kategori-kategori yang terurut secara alami.Sebagai ilustrasi, kelas sosial dapat diklasifikasikan atas kelas atas, menengah, dan bawah; filsafat politik dapat diukur sebagai liberal, moderat, atau konservatif.Peubah-peubah ini dikatakan mempunyai skala ordinal.Untuk semua peubah ordinal, meskipun ada urutan kategori yang jelas, namun perbedaan jarak antara kategorikategori itu tidak diketahui.Misalnya, kita dapat menyimpulkan bahwa seseorang yang dikategorikan sebagai moderat lebih liberal daripada seseorang yang dikategorikan sebagai konservatif, namun kita tidak dapat memberikan nilai numerik bagi sejauh mana keliberalan orang tersebut.

\section{Skala Interval}

Skala interval disamping dapat diurutkan, memiliki sifat bahwa ada perbedaan (jarak numerik tertentu) antara setiap pasang taraf atau nilai peubah.Oleh karenanya, kita dapat membandingkan tidak hanya dalam hal mana yang lebih besar atau lebih tua, namun juga seberapa lebih besar atau seberapa lebih tua. Di dalam skala interval, jarak antara semua taraf yang bersebelahan adalah sama. Teladan peubah interval adalah harga suatu barang, umur, tingkat kelahiran suatu bangsa, jumlah penduduk suatu kota, tingkat pendidikan (dalam tahun), dan pajak pendapatan yang dibayar wajib pajak pada tahun lalu. Pada skala interval, kita dapat membandingkan dua nilai dengan cara mengidentifikasi sifat-sifat berikut:

1. Apakah keduanya berbeda (sifat nominal)

2. Mana yang lebih besar (sifat ordinal)

3. Jarak atau perbedaan antara keduanya (sifat interval)

Misal, kita dapat mengatakan bahwa seseorang yang berumur 60 tahun memiliki umur berbeda dari seseorang yang berumur 20 tahun (secara nominal, keduanya dikatakan berbeda umurnya); dan bahwa yang pertama 40 tahun lebih tua (pembandingan interval). 
Tabel 1 meringkaskan jenis-jenis pembandingan yang dapat dilakukan untuk ketiga taraf pengukuran.Sangat penting untuk menyadari perbedaan antara ketiganya, sebab masingmasing skala pengukuran memiliki sejumlah metode statistika yang paling cocok untuk skala bersangkutan.

Tabel 1. Cara Membandingkan Objek Pengamatan menurut Skala Pengukuran Peubah

\begin{tabular}{clll}
\hline JENIS & \multicolumn{1}{c}{ SKALA } & \multicolumn{1}{c}{ CARA } & TELADAN \\
DATA & PENGUKURAN & MEMBANDINGKAN \\
\hline Kuantitatif & Interval & Apakah berbeda? Harga, \\
& & Mana yang lebih besar? Umur \\
& & Seberapa lebih besar? & \\
\hline Kualitatif & Ordinal & Apakah berbeda?Mana & Kelas sosial \\
& & yang lebih besar? & Status \\
\cline { 3 - 4 } & Nominal & Apakah berbeda? &
\end{tabular}

Tulisan ini lebih memfokuskan bagaimana memperlakukan suatu peubah bebas kualitatif atau yang skala pengukurannya mominal atau ordinal dalam suatu model regresi.Sebagai contoh, misalnya kita ingin menjelaskan fakta bahwa lingkungan sebuah rumah dapat dikategorikan dengan "biasa" dan "baik". Untuk melakukan ini, kita buat suatu peubah artifisial atau peubah boneka yang biasa disebut sebagai peubah dummy yang nilainya 1, misalnya untuk lingkungan "baik" dan nilainya 0 untuk lingkungan "biasa". Dalam teroi statistika, peubah seperti ini sering disebut juga sebagai peubah indikator, yang mana dalam ilustrasi ini adalah peubah indikator untuk lingkungan "baik" karena diberi nilai $1 .^{8}$

\section{Regresi Dummy}

Nama lain Regresi Dummy adalah Regresi Kategori. Regresi ini menggunakan prediktor kualitatif(yang bukan dummy dinamai prediktor kuantitatif). Pembahasan pada regresi ini hanya untuk satu macam peubah dummy dan dikhususkan pada estimasi

\footnotetext{
'Bambang, Juanda, Ekonometrika Pemodelandan Pendugaan, h. 100-101.
} 
parameter dan kemaknaan pengaruh prediktor.Peubah (variabel) dummy disebut juga peubah kategorik, kualitatif, boneka atau peubah dikotomi. Prinsipnya adalah membandingkan karakteristik, misal jenis kelamin (pria dan wanita), tempat tinggal (desa dan kota), dll. Analisis regresi dummy merupakan analisis regresi berganda, hanya saja salah satu peubah bebasnya merupakan peubah kualitatif yang berskala nominal atau ordinal.

Metode yang digunakan adalah mengganti informasi yang bersifat kategori, misal untuk jenis kelamin, PRIA diwakili angka 1 dan WANITA diwakili angka 0, DESA diwakili angka 1 dan KOTA diwakili angka 0,dll. Jika peubah kualitatif tersebut lebih dari dua kategori, jumlah peubah dummy yang dibentuk harus sebanyak $\mathrm{n}-1$, dimana $\mathrm{n}$ adalah banyaknya kategori peubah tersebut. ${ }^{9}$

\section{Model Regresi Dummy dengan Peubah Bebas Kualitatif dengan 2 Kategori (Tanpa Interaksi dengan Peubah Bebas Lainnya)}

Jika kita menggunakan data sampel yang berasal dari teknik sampling dan peubah tak bebasadalah ${ }^{Y}$, kemudian peubah bebas $1(\mathcal{f}$ dan peubah bebas $2(\xi$ tersebut, maka model persamaan dapat ditulis sebagai berikut:

$$
\hat{Y}=\hat{\beta}_{0}+\hat{\beta}_{1} X_{1}+\hat{\beta}_{2} X_{2}+\varepsilon_{i}, i=1,2, \ldots n
$$

Dengan ${ }^{\varepsilon_{i}}$ adalah galat atau sisaan (perbedaaan) antara nilai ${ }^{Y}$ ke${ }^{i}$ yang sebenarnya dengan nilai dugaannya. ${ }^{10}$

Persamaan regresi berganda peubah tak bebas $\hat{Y}$ pada peubah bebas 1 dan peubah bebas $2^{\left(X_{1} \& X_{2}\right)}$ menggambarkan hubungan antara besarnya nilai peubah tak bebas dengan peubah bebasnya.Besarnya nilai ${ }^{Y}$ ditentukan oleh besarnya $X_{1} \& X_{2}$ dengan intersep $\hat{\beta}_{0}$ dan gradient $\beta_{1} \& \beta_{2}$ yang sering juga disebut koefisien regresi.Persamaan regresi tersebut menyatakan bahwa ${ }^{9}$ Norman, R. Draper, dan Harry, Smith, Applied Regression Analysis, Third Edition, (New York: John Wiley \& Sons, Inc, 1998), h. 299.

${ }^{10}$ Bambang, Juanda, Ekonometrika Pemodelandan Pendugaan, h. 101-102. 
nilai $\hat{Y}$ akan bertambah sebesar $\hat{\beta}_{1} \& \hat{\beta}_{2}$ setiap kali nilai $X_{1} \& X_{2}$ bertambah satu satuan, $_{Y}$ dan apabila bernilai nol (0), maka nilai $Y$ akan sebesar $\hat{\beta}_{0} \beta_{1} \& \beta_{2}$ menyatakan besarnya perubahan nilai pada setiap satuan perubahan nilai $X_{1} \& X_{2}$.

$$
\hat{\beta}_{1}=\frac{\Delta \hat{Y}}{\Delta X_{1}}
$$
Dalam banyak kasus, koefisien $\hat{\beta}_{0}$ tidak diinterpretasikan sebagai
besarnya nilai $Y$ apabila ${ }_{1} \& X_{2}$ bernilai 0. Dalam banyak kasus, koefisien hanya berlaku sebagai koefisien penyesuai. ${ }^{11}$

\section{Contoh kasus:}

Seorang peneliti tertarik untuk memprediksi laba dua macam perusahaan (swasta asing dan swasta nasional) bila ditinjau dari besarnya biaya iklan yang dikeluarkan oleh perusahaan untuk membuat iklan mengenai produknya. (Untuk perusahaan swasta asing, laba yang diamati adalah laba yang diperoleh dari hasil penjualan produknya di wilayah Indonesia saja)

Tabel 2. Data Laba Perusahaans

\begin{tabular}{cccc}
\hline NO. & LABA $(\mathbf{Y})$ & TIPE $(\mathbf{X})$ & BIAYA IKLAN(X1) \\
\hline 1 & 9.17 & 1 & 10 \\
\hline 2 & 8.54 & 1 & 12 \\
\hline 3 & 7.68 & 1 & 12 \\
\hline.. & $\ldots$ & $\ldots$ & $\ldots$ \\
\hline.. & $\ldots$ & $\ldots$ & $\ldots$ \\
\hline.. & $\ldots$ & $\ldots$ & $\ldots$ \\
\hline 46 & 6.35 & 0 & 8 \\
\hline 47 & 4.66 & 0 & 6 \\
\hline 48 & 6.98 & 0 & 9 \\
\hline 49 & 4.33 & 0 & 8 \\
\hline 50 & 8.13 & 0 & 8 \\
\hline
\end{tabular}

Source :Deny Kurniawan @200712 113.

${ }^{11}$ Asep, Saefufuddin, dkk, Statistika Dasar, (Jakarta: Grasindo, 2009), h.

${ }^{12}$ https://ineddeni.wordpress.com/2007/08/17/analisis-regresidengan-variabel-dummy/\#more-20, diakses tanggal 2 Januari 2017. 
Selanjutnya akan dilakukan analisis pada data tersebut hingga memperoleh model umum dan model untuk setiap kategorik. Langkah-langkahnya sebagai berikut:

$>$ Membuat variabel dummy bagi ${ }_{2}$, misal $^{Z_{j}}$

$$
\text { Variabel } Z_{j}=\left\{\begin{array}{lr}
0 & \text { (untuk peusaaan swasta asing) } \\
1 \text { (untuk perusaaan swasta nasional) }
\end{array}\right.
$$

Apakah ada interaksi antara peubah ${ }^{X_{1}}$ dan $^{X_{2}}$ ?

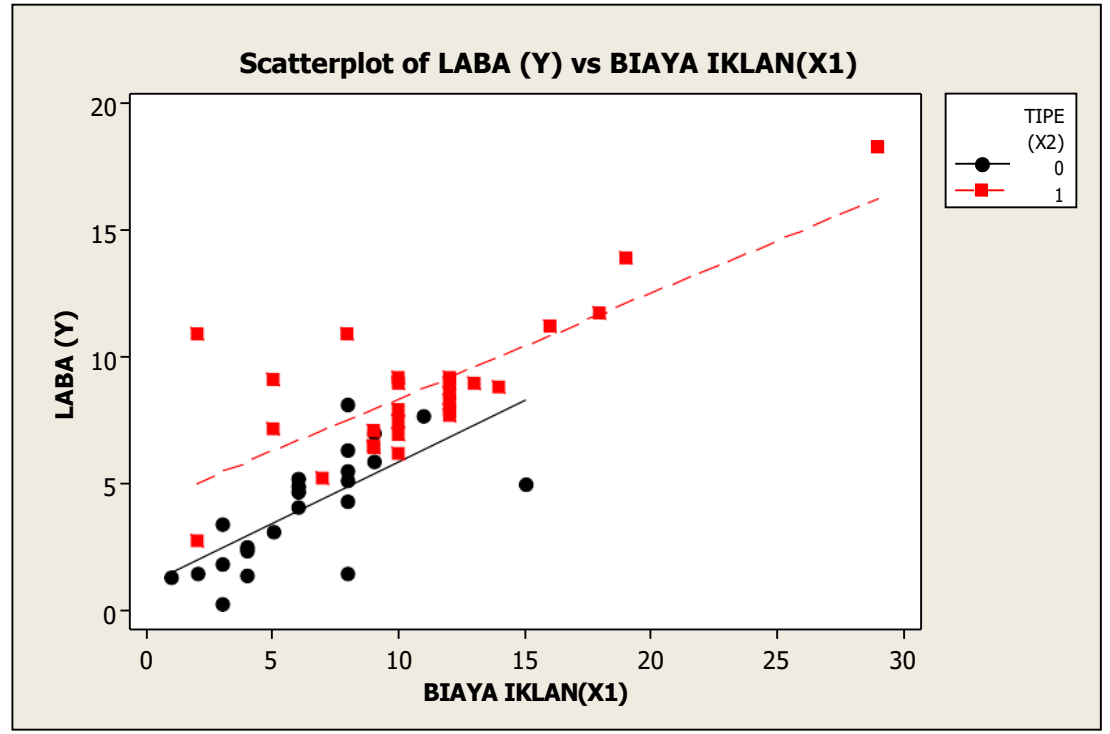

Gambar 1.Scatterplot Data Laba Perusahaan

Berdasarkan Scatterplotpada Gambar 1 menunjukkan bahwa tidak ada interaksi antara peuba和 ${ }^{1}$ dan $^{X_{2}}$. Hal tersebut ditunjukkan dengan 2 garis regresi yang tidak saling berpotongan, sehingga model persamaaan regresinya yaitu:

$$
\ddot{Y}=\ddot{\beta}_{0}+\ddot{\beta}_{1} X_{1}+\ddot{\beta}_{2} Z_{j}+\varepsilon_{i}, i=1,2, \ldots n ; j=0,1
$$

Model kategori untuk perusahaan swasta nasional, ${ }^{\left(Z_{j}=1\right)}$ :

$$
\ddot{Y}=\ddot{\beta}_{0}+\ddot{\beta}_{1} X_{1}+\ddot{\beta}_{2} Z_{j}+\varepsilon_{i}
$$


56|Roza Zelvia

$$
\begin{aligned}
& =\hat{\beta}_{0}+\hat{\beta}_{1} X_{1}+\hat{\beta}_{2}(1)+\varepsilon_{i} \\
= & \left(\hat{\beta}_{0}+\hat{\beta}_{2}\right)+\hat{\beta}_{1} X_{1}+\varepsilon_{i}
\end{aligned}
$$

Model kategori untuk perusahaan swasta asing, $\left(Z_{j}=0\right)$ :

$$
\begin{aligned}
\ddot{Y} & =\ddot{\beta}_{0}+\hat{\beta}_{1} X_{1}+\ddot{\beta}_{2} Z_{j}+\varepsilon_{i} \\
& =\hat{\beta}_{0}+\hat{\beta}_{1} X_{1}+\hat{\beta}_{2}(0)+\varepsilon_{i} \\
& =\hat{\beta}_{0}+\hat{\beta}_{1} X_{1}+\varepsilon_{i}
\end{aligned}
$$

$>$ Perhitungan untuk memperoleh nilai $\hat{\beta}_{0}, \hat{\beta}_{1}$, dan $\hat{\beta}_{2}$ menggunakan software Minitab 16

Output pada Minitab:

Regression Analysis: LABA (Y) versus BIAYA IKLAN(X1), TIPE (X2)

The regression equation is

LABA $(Y)=1.33+0.431$ BIAYA IKLAN $(X 1)+2.66$ TIPE $(X 2)$

Predictor Coef SE Coef T P VIF

Constant $\quad 1.33450 .50782 .630 .012$

BIAYA IKLAN(X1) 0.43066 0.05588 7.71 0.000 1.278

TIPE (X2) $\quad 2.66270 .56264 .730 .0001 .278$

$S=1.75374 \mathrm{R}-\mathrm{Sq}=75.9 \% \mathrm{R}-\mathrm{Sq}(\mathrm{adj})=74.9 \%$

> Setelah diperoleh nilai dugaan untuk tiap paramater tersebut, maka nilai tersebut disubtitusi kedalam model persamaan umum dan model untuk setiap kategori, sehingga diperoleh:

$\ddot{Y}=1.33+0.431 X_{1}+2.66 Z_{j}+\varepsilon_{i}$

Model kategori untuk perusahaan swasta nasional :

$$
\ddot{Y}=3.99+0.431 X_{1}+\varepsilon_{i}
$$

Model kategori untuk perusahaan swasta asing :

$$
\ddot{Y}=1.33+0.431 X_{1}+\varepsilon_{i}
$$


$>$ Interpretasi

Berdasarkan hasil output Minitab 16 di atas dapat dilihat bahwa pada taraf uji nyata 5\%, biaya iklan dan tipe perusahaan berpengaruh nyata (signifikan) terhadap laba perusahaan. Hal ini dapat dilihat dari Nilai-P yang lebih kecil dari 5\%.Model persamaan umum untuk semua kategori yang diperoleh dikatakan model yang baik, hal ini dapat dilihat dari nilai R-Sq (R-Square)yang dihasilkan lebih dari 50\%. Nilai R-Sq sebesar 75,9\%memiliki arti bahwa $75,9 \%$ keragaman dari laba perusahaan dapat dijelaskan oleh biaya iklan dan tipe perusahaan. Berdasarkan model persamaan umum regresi dummy(1) di atas, dapat dinyatakan bahwa nilai dugaan laba perusahaan akan bertambah sebesar 0,431 dan 2,66 setiap kali nilai $X_{1} \& X_{2}$ bertambah satu satuan.

\section{Model Regresi Dummy dengan Peubah Bebas Kualitatif dengan 2 Kategori (Yang Berinteraksi dengan Peubah Bebas Lainnya)}

Data yang digunakan adalah data sampel contoh kasus sebelumnya dengan beberapa perubahan pada datum dengan peubah tak bebasadalah ${ }^{Y}$, kemudian peubah bebas $1^{X_{1}}$ ) dan peubah bebas $2\left(X^{2}\right.$ dan terdapat interaksi antâra dan ${ }^{X_{2}}$, sehingga didapatkan model persamaan sebagai berikut:

$$
\hat{Y}=\hat{\beta}_{0}+\hat{\beta}_{1} X_{1}+\hat{\beta}_{2} X_{2}+\hat{\beta}_{3} X_{1} X_{2}+\varepsilon_{i}, i=1,2, \ldots n
$$

Dengan ${ }^{\varepsilon_{i}}$ adalah galat atau sisaan (perbed
nilai $\mathrm{ke}$ - yang sebenarnya dengan nilai dugaannya. ${ }^{13}$

\section{Contoh kasus:}

Seorang peneliti tertarik untuk memprediksi laba 2 macam perusahaan (swasta asing dan swasta nasional) bila ditinjau dari besarnya biaya iklan yang dikeluarkan oleh perusahaan untuk membuat iklan mengenai produknya. (Untuk perusahaan swasta asing, laba yang diamati adalah laba yang diperoleh dari hasil penjualan produknya di wilayah Indonesia saja)

Bambang, Juanda, Ekonometrika Pemodelandan Pendugaan, h. 103. 
58|Roza Zelvia

Tabel 2. Data Laba Perusahaan

\begin{tabular}{cccc}
\hline NO. & LABA $(\mathbf{Y})$ & TIPE $(\mathbf{X} \mathbf{)})$ & BIAYA IKLAN(X1) \\
\hline 1 & 9,17 & 1 & 10 \\
\hline 2 & 1,32 & 0 & 1 \\
\hline 3 & 8,54 & 1 & 12 \\
\hline.. & $\ldots$ & $\ldots$ & $\ldots$ \\
\hline.. & $\ldots$ & $\ldots$ & $\ldots$ \\
\hline.. & $\ldots$ & $\ldots$ & $\ldots$ \\
\hline 46 & 4,33 & 1 & 7 \\
\hline 47 & 5,2 & 1 & 10 \\
\hline 48 & 6,96 & 0 & 2 \\
\hline 49 & 2,78 & 0 & 19 \\
\hline 50 & 13,9 & 0 & 8 \\
\hline
\end{tabular}

Selanjutnya akan dilakukan analisis pada data tersebut hingga memperoleh model umum dan model untuk setiap kategorik. Langkah-langkahnya sebagai berikut:

$>$ Membuat variabel dummy bagi ${ }^{X_{2}}$, misal ${ }_{j}$ Variabel $Z_{j}=\left\{\begin{array}{lr}0 & \text { (untuk peusahaan swasta asing) } \\ 1 \text { (untuk perusahaan swasta nasional) }\end{array}\right.$

$>$ Apakah ada interaksi antara peubah $X_{1 \text { dan }} X_{2}$ ? 


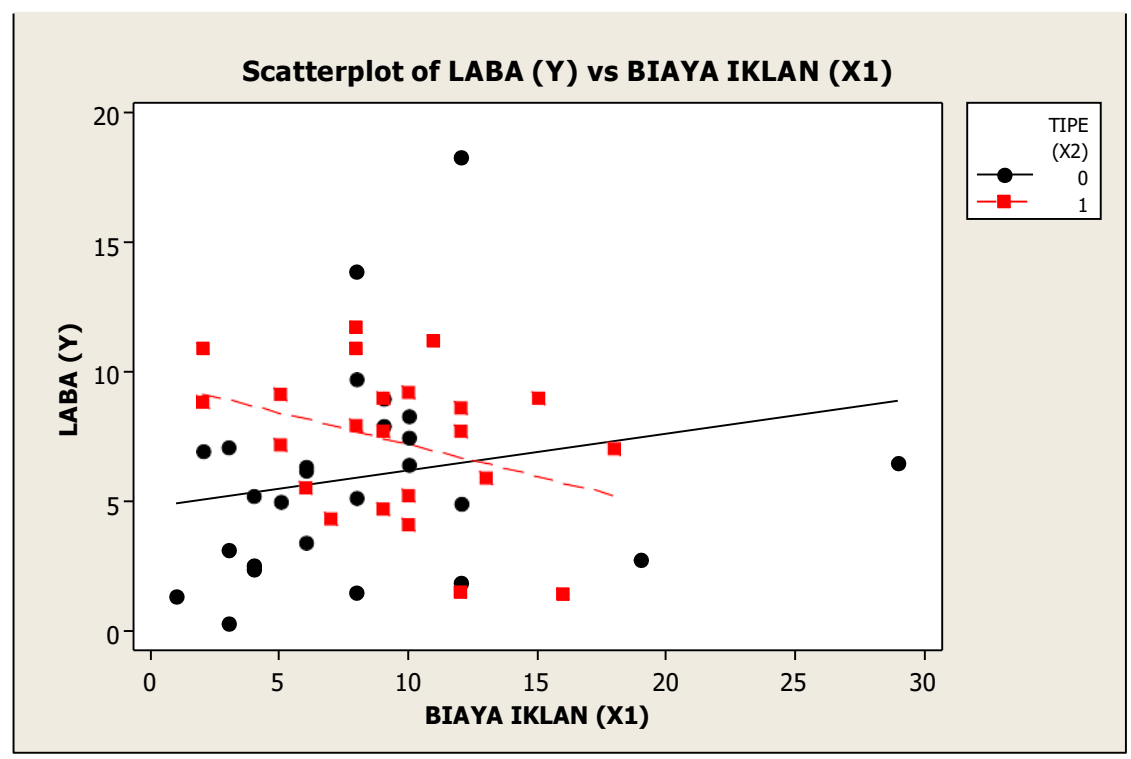

Gambar 2.Scatterplot Data Laba Perusahaan

Berdasarkan Scatterplotpada Gambar 2menunjukkan bahwa ada interaksi antara peubah ${ }_{1}$ dan $^{X_{2}}$ Hal tersebut ditunjukkan dengan 2 garis regresi yang saling berpotongan, sehingga model persamaan regresinya yaitu:

$$
\ddot{Y}=\ddot{\beta}_{0}+\ddot{\beta}_{1} X_{1}+\ddot{\beta}_{2} Z_{j}+\ddot{\beta}_{3} X_{1} Z_{j}+\varepsilon_{i}, i=1,2, \ldots n ; j=0,1
$$

Model kategori untuk perusahaan swasta nasional, ${ }^{\left(Z_{j}=1\right)}$ :

$$
\begin{aligned}
\ddot{Y} & =\ddot{\beta}_{0}+\ddot{\beta}_{1} X_{1}+\ddot{\beta}_{2} Z_{j}+\ddot{\beta}_{3} X_{1} Z_{j}+\varepsilon_{i} \\
& =\hat{\beta}_{0}+\hat{\beta}_{1} X_{1}+\hat{\beta}_{2}(1)+\hat{\beta}_{3}(1) X_{1}+\varepsilon_{i} \\
= & \left(\hat{\beta}_{0}+\hat{\beta}_{2}\right)+\left(\hat{\beta}_{1}+\hat{\beta}_{3}\right) X_{1}+\varepsilon_{i}
\end{aligned}
$$

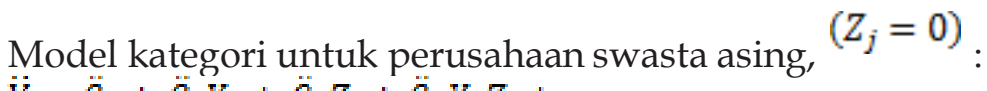

$$
\begin{aligned}
\ddot{Y} & =\hat{\beta}_{0}+\hat{\beta}_{1} X_{1}+\ddot{\beta}_{2} Z_{j}+\ddot{\beta}_{3} X_{1} Z_{j}+\varepsilon_{i} \\
& =\hat{\beta}_{0}+\hat{\beta}_{1} X_{1}+\hat{\beta}_{2}(0)+\hat{\beta}_{3}(1 \cdot 0)+\varepsilon_{i} \\
& =\hat{\beta}_{0}+\hat{\beta}_{1} X_{1}+\varepsilon_{i}
\end{aligned}
$$


60|Roza Zelvia

Berdasarkan Scatterplotpada Gambar 2 menunjukkan bahwa ada interaksi antara peubah ${ }^{X_{1}}$ dan $X_{2}$, sehingga akan dibuat interaksi pada data dengan cara mengkalikan peubah yang berinteraksi.

Tabel 3. Data Laba Perusahaan dengan Interaksi Antara Biaya Iklan dan Tipe Perusahaan

\begin{tabular}{|c|c|c|c|c|}
\hline NO. & $\begin{array}{c}\text { LABA } \\
(\mathbf{Y})\end{array}$ & TIPE $(\mathbf{X} \mathbf{2})$ & $\begin{array}{c}\text { BIAYA } \\
\text { IKLAN(X1) }\end{array}$ & $\begin{array}{c}\text { BIAYA IKLAN } \\
(\mathbf{X} \mathbf{1}) * \text { TIPE (X2) }\end{array}$ \\
\hline 1 & 9,17 & 1 & 10 & 10 \\
\hline 2 & 1,32 & 0 & 1 & 0 \\
\hline 3 & 8,54 & 1 & 12 & 12 \\
\hline.. & $\ldots$ & $\ldots$ & $\ldots$ & $\ldots$ \\
\hline.. & $\ldots$ & $\ldots$ & $\ldots$ & $\ldots$ \\
\hline.. & $\ldots$ & $\ldots$ & $\ldots$ & 7 \\
\hline 46 & 4,33 & 1 & 7 & 10 \\
\hline 47 & 5,2 & 1 & 10 & 0 \\
\hline 48 & 6,96 & 0 & 2 & 0 \\
\hline 49 & 2,78 & 0 & 19 & 0 \\
\hline 50 & 13,9 & 0 & 8 & $\beta_{1}$ \\
\hline
\end{tabular}

Perhitungan untuk memperoleh nilai $\hat{\beta}_{0}, \hat{\beta}_{1}$, dan $\hat{\beta}_{2}$ menggunakan software Minitab 16

Output pada Minitab:

Regression Analysis: LABA (Y) versus BIAYA IKLAN (X1), TIPE (X2), ...

The regression equation is

LABA $(Y)=4.76+0.141$ BIAYA IKLAN $(X 1)+4.85$ TIPE $(X 2)$

- 0.385 BIAYA IKLAN (X1)*TIPE (X2)

Predictor Coef SE Coef $\mathrm{T} \quad \mathrm{P}$

$\begin{array}{lll}\text { Constant } & 4.757 & 1.1764 .040 .000\end{array}$

BIAYA IKLAN (X1) $\quad 0.14100 .11841 .190 .240$

TIPE (X2) $\quad 4.852 \quad 2.2092 .200 .033$

BIAYA IKLAN $(X 1)^{*}$ TIPE $(X 2)-0.38550 .2179-1.770 .084$

$\mathrm{S}=3.45814 \mathrm{R}-\mathrm{Sq}=10.4 \% \mathrm{R}-\mathrm{Sq}(\mathrm{adj})=4.4 \%$ 
Setelah diperoleh nilai dugaan untuk tiap paramater tersebut, maka nilai tersebut disubtitusi kedalam model persamaan umum dan model untuk setiap kategori, sehingga diperoleh:

$\ddot{Y}=4.76+0.141 X_{1}+4.85 Z_{j}-0.385 X_{1} Z_{j}+\varepsilon_{i}$

Model kategori untuk perusahaan swasta nasional :

$$
\ddot{Y}=9.61-0.244 X_{1}+\varepsilon_{i}
$$

Model kategori untuk perusahaan swasta asing :

$$
\ddot{Y}=4.76+0.141 X_{1}+\varepsilon_{i}
$$

$>$ Interpretasi

Berdasarkan hasil output Minitab 16 di atas dapat dilihat bahwa pada taraf uji nyata $5 \%$, biaya iklan dan interaksi antara biaya iklan dan tipe perusahaan tidak berpengaruh nyata (signifikan) terhadap laba perusahaan. Hal ini dapat dilihat dari Nilai-P pada biaya iklan dan interaksi antara biaya iklan dan tipe perusahaan yang lebih besar dari 5\%.Sementara tipe perusahaan berpengaruh nyata (signifikan) terhadap laba perusahaan.Hal ini dapat dilihat dari Nilai-P pada tipe perusahaan yang lebih kecil dari 5\%.Model persamaan umum untuk semua kategori yang diperoleh dikatakan model yang kurang baik, hal ini dapat dilihat dari nilai R-Sq (R-Square) yang dihasilkan kurang dari $50 \%$. Nilai R-Sq sebesar 10,4\% memiliki arti bahwa 10,4\% keragaman dari laba perusahaan dapat dijelaskan oleh biaya iklan dan tipe perusahaan serta interaksi antara biaya iklan dan tipe perusahaan. Berdasarkan model persamaan umum regresi dummy(2) di atas, dapat dinyatakan bahwa nilai dugaan laba perusahaan akan bertambah sebesar 4,76 dan 4,85 setiapkali nilai $X_{1} \& X_{2}$ bertambah satu satuan, dan akan berkurang sebesar 0,385 setiap kali nilai interaksi antara $X_{1} X_{2}$ bertambah satu satuan.

\section{Model Regresi Dummy dengan Peubah Bebas Kualitatif dengan 3 Kategori atau Lebih}

Sebagai ilustrasi, misalnya kita ingin mengembangkan suatu model untuk menduga gaji karyawan ( ) berdasarkan pengalaman kerja $X_{f}$ dan pendidikan ( $X_{\mathcal{F}}$ karyawan tersebut, dengan model sebagai berikut : 
62|Roza Zelvia

$$
Y=\beta_{0}+\beta_{1} X_{1}+\beta_{2} X_{2}+\varepsilon_{i}, i=1,2, \ldots n
$$

Peubah pendidikan karyawan $\left.{ }^{(}{ }^{2}\right)$ misalnya dikategorikan ke dalam 3 kategori, yaitu lulusan "Sekolah Dasar (SD)", "Sekolah Lanjut (SL)", dan "Perguruan Tinggi (PT)".

Untuk pemodelan ini, misalnya telah dikumpulkan data ke-3 peubah dari $n$ sampel responden karyawan yang diambil secara acak, sehingga model regresi sampelnya adalah sebagai berikut:

$$
\hat{Y}=\hat{\beta}_{0}+\hat{\beta}_{1} X_{1}+\hat{\beta}_{2} X_{2}+\varepsilon_{i}, i=1,2, \ldots n
$$

Misalkan dilakukan 2 cara pemberian nilai untuk $X_{2}$.
$>$ Membuat variabel dummy bagi ${ }_{2}{ }_{2}$, misal $Z_{j}$

$$
\text { Variabel } Z_{j}=\left\{\begin{array}{l}
0 ; \text { untuk lulusan } S D \\
1 ; \text { untuk lulusan } S L \\
2 ; \text { untuk lulusan } P T
\end{array}\right.
$$

$\left(X_{2}\right)$ Untuk model dengan cara pemberian nilai untuk peubah $\left(X_{2}\right)$ tersebut dapat diuraikan untuk masing-masing kategorinya, yaitu dengan memasukkan nilai peubah kategori tersebut.

$$
\ddot{Y}=\ddot{\beta}_{0}+\ddot{\beta}_{1} X_{1}+\ddot{\beta}_{2} Z_{j}+\varepsilon_{i}, i=1,2, \ldots n ; j=0,1,2
$$

Model kategori untuk lulusan "SD", ${ }^{\prime}$ :

$$
\begin{aligned}
\ddot{Y} & =\ddot{\beta}_{0}+\ddot{\beta}_{1} X_{1}+\ddot{\beta}_{2} Z_{j}+\varepsilon_{i} \\
& =\hat{\beta}_{0}+\hat{\beta}_{1} X_{1}+\hat{\beta}_{2}(0)+\varepsilon_{i} \\
& =\hat{\beta}_{0}+\hat{\beta}_{1} X_{1}+\varepsilon_{i}
\end{aligned}
$$

Model kategori untuk lulusan "SL", ${ }^{\left(Z_{j}=1\right)}$ :

$$
\begin{aligned}
\ddot{Y} & =\ddot{\beta}_{0}+\ddot{\beta}_{1} X_{1}+\ddot{\beta}_{2} Z_{j}+\varepsilon_{i} \\
& =\hat{\beta}_{0}+\hat{\beta}_{1} X_{1}+\hat{\beta}_{2}(1)+\varepsilon_{i} \\
& =\left(\hat{\beta}_{0}+\hat{\beta}_{2}\right)+\hat{\beta}_{1} X_{1}+\varepsilon_{i}
\end{aligned}
$$

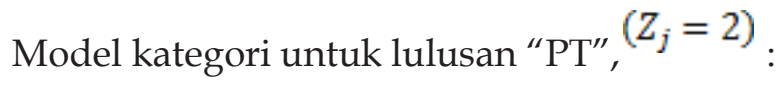

$$
\ddot{Y}=\ddot{\beta}_{0}+\ddot{\beta}_{1} X_{1}+\ddot{\beta}_{2} Z_{j}+\varepsilon_{i}
$$


$\begin{aligned} & =\hat{\beta}_{0}+\hat{\beta}_{1} X_{1}+\hat{\beta}_{2}(2)+\varepsilon_{i} \\ = & \left(\hat{\beta}_{0}+2 \hat{\beta}_{2}\right)+\hat{\beta}_{1} X_{1}+\varepsilon_{i}\end{aligned}$

Dari ketiga model (3), (4), dan (5) ini terlihat jelas bahwa jika pengalaman karyawan sama, maka perbedaan gaji tiap jenjang pendidikan sama, yaitu sebesar nilai dugaan koefisien $\beta_{2}$

Dalam realitas, perbedaan gaji tiap jenjang pendidikan belum tentu sama. Oleh karena itu, sebaiknya menggunakan cara kedua yaitu dengan mengembangkan peubah dummyyang nilainya hanya ada dua kemungkinan, yaitu 0 dan 1 . Aturan umumnya adalah "jika peubah bebas kualitatif (skala nominal atau ordinal) nilainya.ada k kategori maka kita harus menggunakan k1 peubah dummy.

Untuk ilustrasi ini, ada 2 peubah dummy karena ada 3 kategori. Misalnya pemberian nilai untuk 2 peubah dummy tersebut adalah sebagai berikut:

\begin{tabular}{ccc}
\hline Pendidikan & $\mathrm{D}_{1}=\mathrm{D}_{\mathrm{SL}}$ & $\mathrm{D}_{2}=\mathrm{D}_{\mathrm{pT}}$ \\
\hline $\mathrm{SD}$ & 0 & 0 \\
\hline $\mathrm{SL}$ & 1 & 0 \\
\hline $\mathrm{PT}$ & $\underline{0}$ & $\underline{1}$
\end{tabular}

Cara kedua dengan menggunakan peubah dummyini dapat juga diungkapkan sebagai berikut:

$D_{1}=D_{S L}=\left\{\begin{array}{l}1, \text { jika lulusanSL } \\ 0, \text { jika selainnya }\end{array}\right.$
$D_{2}=D_{P T}=\left\{\begin{array}{l}1, \text { jika lulusanPT } \\ 0, \text { jika selainnya }\end{array}\right.$

Untuk pemodelan dengan menggunakan peubah dummy ini, misalnya telah dikumpulkan data dari $\mathrm{n}$ contoh responden karyawan yang diambil secara acak, sehingga model regresi contohnya adalah sebagai berikut :

$$
\hat{Y}=\hat{\beta}_{0}+\hat{\beta}_{1} X_{1}+\hat{\beta}_{2} D_{S L}+\hat{\beta}_{3} D_{P T}+\varepsilon_{i}, i=1,2, \ldots n
$$

Model dengan menggunakan peubah dummy tersebut dapat diuraikan untuk masing-masing kategorinya, yaitu dengan memasukkan nilai peubah dummy tersebut. 
64|Roza Zelvia

Model kategori untuk lulusan "SD", $\left(D_{S L}=D_{P T}=0\right)$ :

$$
\begin{aligned}
\hat{Y} & =\hat{\beta}_{0}+\hat{\beta}_{1} X_{1}+\hat{\beta}_{2} D_{S L}+\hat{\beta}_{3} D_{P T}+\varepsilon_{i} \\
& =\hat{\beta}_{0}+\hat{\beta}_{1} X_{1}+\hat{\beta}_{2}(0)+\hat{\beta}_{3}(0)+\varepsilon_{i} \\
& =\hat{\beta}_{0}+\hat{\beta}_{1} X_{1}+\varepsilon_{i}
\end{aligned}
$$

Model kategori untuk lulusan "SL", $\left(D_{S L}=1, D_{P T}=0\right)$ :

$$
\begin{aligned}
\hat{Y} & =\hat{\beta}_{0}+\hat{\beta}_{1} X_{1}+\hat{\beta}_{2} D_{S L}+\hat{\beta}_{3} D_{P T}+\varepsilon_{i} \\
& =\hat{\beta}_{0}+\hat{\beta}_{1} X_{1}+\hat{\beta}_{2}(1)+\hat{\beta}_{3}(0)+\varepsilon_{i} \\
& =\left(\hat{\beta}_{0}+\hat{\beta}_{2}\right)+\hat{\beta}_{1} X_{1}+\varepsilon_{i}
\end{aligned}
$$

Model kategori untuk lulusan " $\mathrm{PT}^{\prime},\left(D_{S L}=0, D_{P T}=1\right)$ :

$$
\begin{aligned}
\hat{Y} & =\hat{\beta}_{0}+\hat{\beta}_{1} X_{1}+\hat{\beta}_{2} D_{S L}+\hat{\beta}_{3} D_{P T}+\varepsilon_{i} \\
& =\hat{\beta}_{0}+\hat{\beta}_{1} X_{1}+\hat{\beta}_{2}(0)+\hat{\beta}_{3}(1)+\varepsilon_{i} \\
& =\left(\hat{\beta}_{0}+\hat{\beta}_{3}\right)+\hat{\beta}_{1} X_{1}+\varepsilon_{i}
\end{aligned}
$$

Dari ketiga model (6), (7) dan (8) ini terlihat jelas bahwa jika pengalaman karyawan sama, maka perbedaan gaji tiap jenjang pendidikan dapat berbeda. Interpretasi dari koefisien modelnya adalah sebagai berikut:

$\beta_{0}$ :rata-rata gaji karyawan lulusan SD yang belum berpengalaman

$\beta_{1}$ : rata-rata kenaikan gaji karyawan jika pengalamannyasama

$\hat{\beta}_{2}$ : rata-rata perbedaaan gaji karyawan lulusan SL dengan lulusan

SD jika pengalamannya $\left({ }^{X_{1}}\right.$ sama

$\hat{\beta}_{3}$ : rata-rata perbedaaan gaji karyawan lulusan PT dengan lulusan SD jika pengalamannya ( ${ }^{\prime}{ }_{1}$ sama

$\beta_{2-} \beta_{3}$ : rata-rata perbedaaan gaji karyawan lulusan PT dengan lulusan SL jika pengalamannya ( ${ }^{\mathcal{X}}{ }^{1} \mathrm{sama}^{14}$

Berdasarkan penjelasan beberapa model persamaan regresi dummy di atas bahwa analisis regresi dummydigunakan hanya untuk data yang salah satu atau beberapa peubah bebasnya berskala nominal atau ordinal. Namun dalam praktiknya lebih sering digunakan peuba berskala nominal untuk mendapatkan

\footnotetext{
${ }^{14}$ Bambang, Juanda, Ekonometrika Pemodelandan Pendugaan, h. 105-107.
} 
hasil dugaan (data sampel) dengan keadaan sebenarnya (data populasi).Pada data kasus ekonomi banyak sekali ditemui peubahpeubah yang berskala nominal ataupun ordinal (data kualitatif), sehingga metode statistika yaitu analisis regresi dummy ini sering sekali digunakan sebagai alat bantu untuk menyelesaikan masalah atau melihat hubungan pada data-data ekonomi.

\section{Simpulan}

Analisis regresi adalah suatu analisis yang digunakan untuk melihat hubungan antar peubah yang diduga memiliki hubungan sebab akibat.Data yang dipakai minimal memiliki satu peubah tak bebas dan lebih dari satu peubah bebas.Dimana peubah tak bebas merupakan peubah yang dipengaruhi oleh peubah bebas. Pada analisis regresi dummy peubah bebas bersifat kategorik atau numerik dengan skala pengukuran nominal, ordinal atau interval. Peubah bebas pada analisis regresi dummy boleh lebih dari satu, dimana peubah-peubah tersebut bisa saling berinteraksi atau tidak saling interaksi. Hal ini ditunjukkan dengan menggambar scatterplot dari data tersebut. Analisis regresi dummy adalah salah satu analisis yang dipakai pada data ekonomi, yang dimana salah satu peubah bebas dari data tersebut berupa data kualitatif dengan skala pengukuran nominal atau ordinal.

\section{Daftar Pustaka}

Ahmad, Ansori Mattjik, dan I Made, Sumertajaya, Perancangan Percobaan dengan Aplikasi SAS dan Minitab, (Bogor: IPB Press, 2000).

Asep, Saefufuddin, dkk, Statistika Dasar, (Jakarta: Grasindo, 2009).

Bambang, Juanda, Ekonometrika Pemodelandan Pendugaan, (Bogor: IPB Press, 2009).

https://ineddeni.wordpress.com/2007/08/17/analisis-regresidengan-variabel-dummy/\#more-20, diakses tanggal 2 Januari 2017. 
66|Roza Zelvia

Imam, Machali, Statistik Manajemen Pendidikan, (Yogyakarta:

Kaukaba Dipantara (Anggota Ikapi), 2015).

Noegroho, Boedijoewono, Pengantar Statistika Ekonomi dan Bisnis, Jilid 1 (Deskriptif), (Yogyakarta: UPP STIM YKPN, 2016).

Norman, R. Draper, dan Harry, Smith, Applied Regression Analysis, Third Edition, (New York: John Wiley \& Sons, Inc, 1998). 